\title{
Designing full-scale biodigestion plants for the treatment of vinasse in sugarcane biorefineries: How phase separation and alkalinization impact biogas and electricity production costs?
}

\author{
Lucas Tadeu Fuess ${ }^{a, *}$, Moacir Messias de Araújo Júnior ${ }^{b}$, \\ Marcelo Loureiro Garcia ${ }^{c}$, Marcelo Zaiat ${ }^{a}$ \\ a Biological Processes Laboratory (LPB), São Carlos School of Engineering (EESC), University of São Paulo (USP), Av. \\ João Dagnone, 1100, Santa Angelina, São Carlos, São Paulo 13563-120, Brazil \\ b Bio Proj Tecnologia Ambiental, R. Major José Inácio, 2920, Centro, São Carlos, São Paulo 13560-161, Brazil \\ c Institute of Geosciences and Exact Sciences, UNESP-Univ Estadual Paulista, Av. 24-A, 1515, Bela Vista, Rio Claro, \\ São Paulo 13506-900, Brazil
}

\section{A R T I C L E I N F O}

\section{Article history}

Received 18 August 2016

Received in revised form 23 January

2017

Accepted 25 January 2017

Available online 3 February 2017

Keywords:

Ethanol biorefinery

Vinasse management

Full-scale biodigestion

Phase separation

Economic feasibility

\begin{abstract}
A B S T R A C T
Anaerobic digestion (AD) is the most suitable approach for the management of vinasse in sugarcane distilleries because both environmental adequacy and bioenergy recovery could be achieved through biogas production. Because the literature lacks data on the implementation and operation of full-scale AD plants for enhanced energy recovery from vinasse, this study presents different designs for $\mathrm{AD}$ plants applied to vinasse in large-scale distilleries, considering both single- and two-phase schemes and different alkalizing strategies. Investment and operating costs and biogas and electricity production costs were obtained for each case. The results indicate that phase separation is economically feasible when scaling up AD plants in biorefineries. Despite the higher capital and operating costs in such schemes, the estimated biogas and electricity production costs reached equivalent or lower values compared with those of single-phase AD layouts, depending on the alkalizing strategy used. With respect to the alkalizing strategy, the best results were associated with sodium hydroxide dosing and/or effluent recirculation, with electricity costs reaching values 1.8- to 2.3-fold lower than grid electricity. In contrast, the competitive use of sodium bicarbonate in $A D$ plants for treating vinasse requires further dosing optimization.
\end{abstract}

( 2017 Institution of Chemical Engineers. Published by Elsevier B.V. All rights reserved.
1. Introduction

The proper management of vinasse is one of the major issues facing sugarcane-based ethanol biorefineries due to environmental concerns associated with fertirrigation, the main technological approach used in the sucro-alcohol industry (Fuess and Garcia, 2014). The process constitutes the direct land application of in natura vinasse into sugarcane fields to recycle nutrients and water to the crop (Dias et al.,
2015). Although such a practice reduces the input of mineral fertilizers, which also enhances economic benefits, the continuous, long-term land application of vinasse has been frequently associated with the lack of proper technical expertise and tends to reduce crop yields, the productive capacity of soils, and even the quality of surrounding water bodies (Fuess and Garcia, 2014). Additional drawbacks from fertirrigation include bioenergy losses due to the uncontrolled conversion of organic matter by soil microbial populations, which also enhances the

\footnotetext{
* Corresponding author.

E-mail addresses: ltfuess@sc.usp.br (L.T. Fuess), moacir@bioproj.com.br (M.M. de Araújo Júnior), mlgarcia@rc.unesp.br (M.L. Garcia), zaiat@sc.usp.br (M. Zaiat). 
emission of greenhouse gases, such as nitrogen oxides and methane (Oliveira et al., 2013).

Anaerobic digestion (AD), or biodigestion, is considered one of the most suitable technological approaches to the management of vinasse in biorefineries because both environmental adequacy and bioenergy recovery could be achieved through the controlled conversion of organic matter into biogas without significant losses in the fertilizing potential of vinasse (Fuess and Garcia, 2015; Moraes et al., 2015; Ryan et al., 2009). A large number of studies have investigated the application of $A D$ to sugarcane vinasse (Bories et al., 1988; Costa et al., 1986; Craveiro et al., 1986; Ferraz et al., 2016; Fuess et al., 2017; Kumar et al., 2007; Siqueira et al., 2013; Souza et al., 1992) in an effort to optimize treatment performances by applying different reactor configurations and operating strategies. However, most studies have been based on lab-scale conditions; few have addressed pilot- to full-scale systems. The scale-up of efficient anaerobic systems is imperative for identifying operating drawbacks and for precisely assessing the energetic potential of the biogas from sugarcane vinasse.

Due to the expected increased demand for ethanol, decision makers in the sucro-energetic sector should be supplied with detailed techni$\mathrm{cal}$ and economic information on the implementation of full-scale $\mathrm{AD}$ systems in biorefineries for the efficient exploitation of vinasse as fertilizer and feedstock for bioenergy recovery. In this context, the design of biodigestion plants for ethanol biorefineries should be highlighted due to various means for enhanced bioenergy extraction from vinasse. Two major aspects are addressed in this study: phase separation applications in $\mathrm{AD}$ plants, i.e., uncoupling acidogenesis from methanogenesis, and assessments of different alkalizing strategies for stable conversion processes.

Regarding phase separation, studies have indicated that the pre-acidification of organic matter-rich effluents may lead to several advantages in methane production and treatment performance. Hydrolysis steps could be enhanced during the acidogenic phase by applying sufficient residence times in digesters (Hallenbeck, 2009). This would improve the biodegradability of complex organic matrices, such as vinasse, in the methanogenic phase (Ke et al., 2005). Greater process stability and energy yields would also result from phase separation, because methanogens would be less exposed to the negative effects of acid accumulation (Ferraz et al., 2016; Yu et al., 2015). This would also lead to lower alkalizing compound input requirements for digesters. Although phase separation would reduce chemical costs, this practice would require additional tanks and equipment and thereby increase capital and maintenance costs.

With respect to alkalizing strategies, the application of chemicals to raw vinasse is a key factor for obtaining high treatment performances, and specific composition characteristics, such as high carbohydrate concentrations, low $\mathrm{pH}$ and absence of alkalinity, provide favorable conditions for rapid vinasse acidification (Boncz et al., 2012). Sodium bicarbonate $\left(\mathrm{NaHCO}_{3}\right)$ has been frequently applied as an alkalizing compound in bench-scale AD systems for vinasse treatments (Döll and Foresti, 2010; Ferraz et al., 2016; Fuess et al., 2017; Harada et al., 1996; Siqueira et al., 2013). These adjustments usually enable reactors to deal with high organic loading rates (OLRs). Sodium hydroxide ( $\mathrm{NaOH})$ (Souza et al., 1992) and calcium carbonate (or limestone- $\mathrm{CaCO}_{3}$ ) (Goyal et al., 1996; Seth et al., 1995) have also been commonly used in treating vinasse prior to methane production. Despite the added reactor stability, the use of high chemical doses negatively affects the economic favorability of scaling-up AD plants. Studies have proposed the recycling of treated effluent because the bicarbonate produced from methanogen metabolism can be used to neutralize influent wastewaters (Barrera et al., 2016; Nandy et al., 2002; van Haandel, 2005). Urea $\left(\mathrm{CH}_{4} \mathrm{~N}_{2} \mathrm{O}\right)$ application has also been tested (Boncz et al., 2012) to provide alkalinity to methanogens and increase nitrogen levels in the treated vinasse and thereby improve its fertilization potential (van Haandel, 2005). However, the potential accumulation of ammonia within the reactors could lead to inhibitory effects over the methanogenic populations and thus impair the bioenergy recovery from vinasse (Boncz et al., 2012).

Overall, the various methods for full-scale AD systems in treating sugarcane vinasse require careful assessments of their benefits and drawbacks to determine their appropriate implementation in distilleries. This study aims to evaluate single- and two-phase schemes for $\mathrm{AD}$ plants and different alkalizing strategies for digesting vinasse in large-scale sugarcane-based distilleries. These alkalizing strategies include the application of chemicals $\left(\mathrm{NaHCO}_{3}\right.$ or $\left.\mathrm{NaOH}\right)$ and/or effluent recirculation. Detailed investment costs were calculated for the AD plants, as well as biogas production costs for each case. Electricity production costs from biogas were also estimated for power plants with internal combustion engines (ICEs). Performance data for AD systems and alkalizing compound dosages were obtained from experimental data. Ethanol and vinasse flow rates were estimated based on the typical characteristics of the Brazilian sucro-energetic sector.

\section{Methods}

\subsection{Basic input data: sugarcane biorefinery and AD systems}

A large-scale, annexed, sugarcane-based biorefinery with a milling capacity of $4 \times 10^{6}$ tons of sugarcane (TC) per harvest was used as the baseline for calculations. Table 1 shows the input data for the biorefinery, including ethanol yield and ethanol and vinasse flow rates. The harvesting period was set at 232 days, i.e., the average duration of the sugarcane season in Brazil (Table 1; CONAB, 2011).

Reference data for the single- and two-phase biodigestion systems are also presented in Table 1. Performance data for the single-phase AD system were obtained from Ferraz et al. (2016). Data for the acidogenic and methanogenic steps of the two-phase AD system were collected from Fuess et al. (2016) and (2017), respectively. Biohydrogen production/collection was not considered in this study, i.e., the acidogenic phase was considered only for the enhancement of the vinasse biodegradability (Ferraz et al., 2016). The AD performance data refers to the thermophilic temperature conditions $\left(55^{\circ} \mathrm{C}\right)$.

\subsection{Design criteria for AD systems: reactors and alkalinization}

The design of the $\mathrm{AD}$ plants was based on reactor configurations reported by Fuess et al. (2016) and (2017) for fixed-film digesters. Such systems are advantageous compared with suspended-biomass reactors because immobilized cells are less sensitive to environmental variations (e.g., $\mathrm{pH}$, temperature, and organic loading) and have higher substrate consumption rates (Chan et al., 2009). For the acidogenic phase, a set of conventional packed-bed reactors (APBRs) was designed using low-density polyethylene (LDPE) as the support material. The OLR was set at $84.2 \mathrm{~kg}$-COD m$^{-3} \mathrm{~d}^{-1}$ (Fuess et al., 2016), excluding chemicals used to adjust the $\mathrm{pH}$ of the raw sugarcane vinasse. With respect to the methanogenic phase, structured-bed reactors (ASTBRs) were designed for an OLR of $25 \mathrm{~kg}^{-C O D ~ ~^{-3}} \mathrm{day}^{-1}$, regardless of the phase separation. The ASTBRs, as alternatives to the random arrangement of support materials in packed-bed systems (Fig. 1), combine the advantages of immobilized-cell growth with high bed porosity to prevent the accumulation of extracellular polymeric substances and suspended solids (Camiloti et al., 2014). Polyurethane was considered the support material in methanogenic reactors (Fuess et al., 2017). The vinasse $\mathrm{pH}$ and alkalinity were adjusted as further presented. No cooling system was designed because vinasse might naturally reach the required temperature (from $85-90^{\circ} \mathrm{C}$ to $55^{\circ} \mathrm{C}$ ) in intermediate storage tanks or in thermal exchangers prior to reaching the treatment plant. 


\section{Table 1 - Input data for both sugarcane biorefinery and AD plants.}

Annexed biorefinery

Harvest period (days)

Milling capacity (TC season ${ }^{-1}$ )

Ethanol yield $\left(\mathrm{L} \mathrm{TC}^{-1}\right)^{\mathrm{b}}$

Annual ethanol production $\left(\mathrm{m}^{3}\right)$

Ethanol flow rate $\left(\mathrm{m}^{3} \mathrm{~d}^{-1}\right)$

Vinasse-to-ethanol proportion ${ }^{c}$

Vinasse flow rate $\left(\mathrm{m}^{3} \mathrm{~d}^{-1}\right)$

Vinasse characterization

\section{$232^{\mathrm{a}}$}

$4 \times 10^{6}$

53.4

$213.6 \times 10^{3}$

920.7

10

9207.00

$\mathrm{COD}^{\mathrm{d}}: 28.3 \mathrm{gL}^{-1}$

BOD $^{\text {d,e }}: 14.6 \mathrm{gL}^{-1}$

Sulfate $^{\mathrm{d}}: 1700 \mathrm{mg} \mathrm{L}^{-1}$
VSS $^{\text {d,f: }}: 818 \mathrm{mg} \mathrm{L}^{-1}$

Potassium: $3575 \mathrm{mg} \mathrm{L}^{-1}$ $\mathrm{pH}^{\mathrm{d}}: 4.5$ (raw vinasse)

\section{Biodigestion plants}

Single-phaseg

Two-phase
Acidogenic step $^{d}$

Methanogenic step ${ }^{\mathrm{h}}$
OLR $=25 \mathrm{~kg}-\mathrm{COD} \mathrm{m}^{-3} \mathrm{day}^{-1}$

COD removal $=60.7 \%$

Methane production $=0.234 \mathrm{Nm}^{3}-\mathrm{CH}_{4} \mathrm{~kg}^{-1} \mathrm{COD}$-removed

Biogas- $\mathrm{CH}_{4}$ composition: $\mathrm{CH}_{4}(58.4 \%)+\mathrm{CO}_{2}(40.6 \%)+\mathrm{H}_{2} \mathrm{~S}(1.0 \%)$

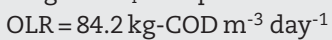

COD removal $=21.2 \%$

$\mathrm{OLR}=25 \mathrm{~kg}_{-\mathrm{COD} \mathrm{m}}{ }^{-3}$ day $^{-1}$

COD removal $=73.9 \%$

Methane production $=0.301 \mathrm{Nm}^{3}-\mathrm{CH}_{4} \mathrm{~kg}^{-1} \mathrm{COD}$-removed

Biogas- $\mathrm{CH}_{4}$ composition: $\mathrm{CH}_{4}(70.0 \%)+\mathrm{CO}_{2}(29.0 \%)+\mathrm{H}_{2} \mathrm{~S}(1.0 \%)$

Notes: a ${ }^{\mathrm{C}} \mathrm{CNAB}$ (2011); b ${ }^{\mathrm{M}}$ oraes et al. (2014); ${ }^{\mathrm{c}}$ Dias et al. (2015); ${ }^{\mathrm{d}}$ Fuess et al. (2016); ${ }^{\mathrm{e}}$ Biochemical oxygen demand; fVolatile suspended solids; gerraz et al. (2016); ${ }^{\text {h}}$ Fuess et al. (2017).
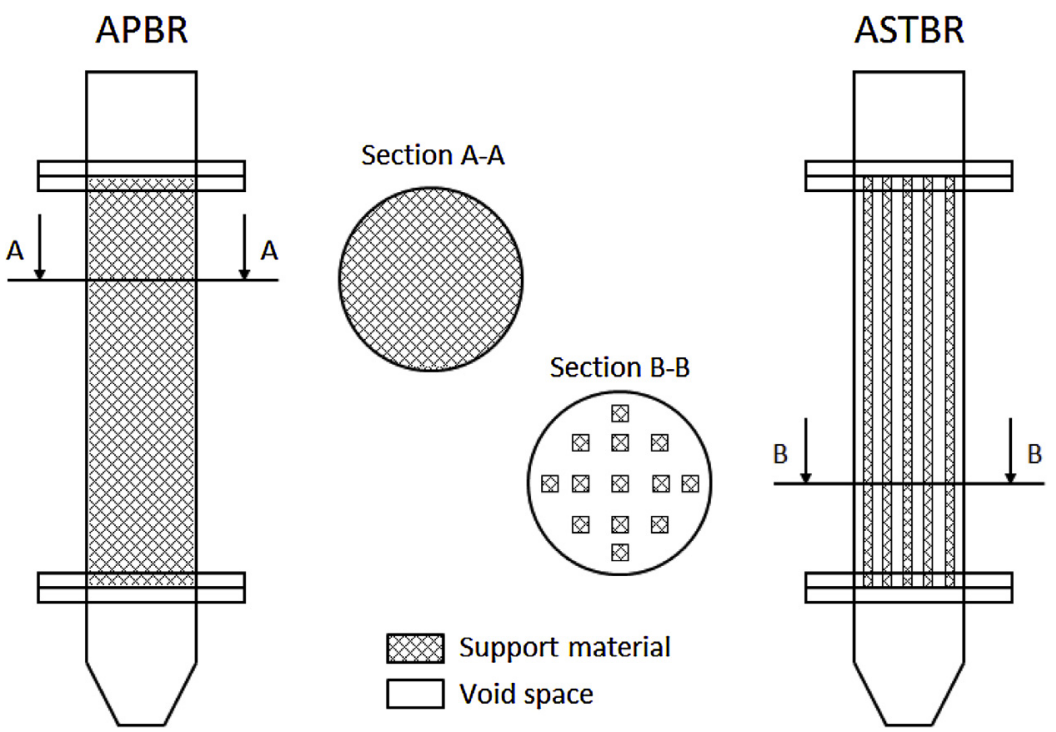

Fig 1 - Sketch of packed- (APBR) and structured-bed (ASTBR) reactors.

The alkalizing strategies for the methanogenic reactors included the application of chemicals $\left(\mathrm{NaHCO}_{3}\right.$ or $\left.\mathrm{NaOH}\right)$ with or without effluent recirculation. For scenarios without effluent recirculation, chemicals were applied during the entire operation of the $\mathrm{AD}$ plant, i.e., 232 days. For cases with recirculation, chemicals were applied only during the start-up period of the methanogenic reactors (i.e., the first 50 days; Fuess et al., 2017). Additional scenarios with only effluent recirculation were also assessed. Table 2 summarizes each studied scenario and also presents the mass flow rates for the alkalizing compounds. $\mathrm{NaHCO}_{3}$ dosages for single- and two-phase systems were 0.36 and 0.28 g- $\mathrm{NaHCO}_{3} \mathrm{~g}^{-1} \mathrm{COD}$-vinasse (Table 2), which were respectively obtained from Ferraz et al. (2016) and Fuess et al. (2017). A NaOH dosage of $4 \mathrm{~g}-\mathrm{NaOH} \mathrm{kg}{ }^{-1} \mathrm{COD}$-vinasse $\left(4 \times 10^{-3}\right.$ g-NaOH g ${ }^{-1} \mathrm{COD}$-vinasse) (Souza et al., 1992) was con- sidered for both single- and two-phase systems (Table 2). The effluent recirculation ratio (R) was 15, as proposed by Barrera et al. (2016) (Table 2).

\subsection{Basic calculations: biogas flow rate, electricity production and operating parameters}

Biogas flow rate (BFR, $\mathrm{Nm}^{3} \mathrm{~h}^{-1}$ ) was calculated according to Eq. (1), where the terms VFR, COD, $E R_{\mathrm{COD}}, M Y$ and $f_{\mathrm{CH} 4}$, respectively, represent the vinasse flow rate $\left(\mathrm{m}^{3} \mathrm{~h}^{-1}\right)$, the vinasse COD prior to methanogenesis $\left(\mathrm{gL}^{-1}\right.$ or $\mathrm{kg} \mathrm{m}^{-3}$ ), the COD removal efficiency in the methanogenic reactors (dimensionless-Eq. (2), the methane yield ( $\mathrm{Nm}^{3}-\mathrm{CH}_{4} \mathrm{~kg}^{-1} \mathrm{COD}$-removed) and the methane content in the biogas (dimensionless). In Eq. (2), the terms $C O D_{\text {influent }}$ and $C O D_{\text {effluent }}$ represent the vinasse $C O D$ 
Table 2 - Characterization of the alkalizing strategies assessed for single- and two-phase AD plants.

\begin{tabular}{|c|c|c|c|c|c|c|c|}
\hline \multirow[t]{2}{*}{ Scenario } & \multirow{2}{*}{$\begin{array}{l}\text { Phase } \\
\text { separation }\end{array}$} & \multirow{2}{*}{$\begin{array}{l}\text { COD-vinasse } \\
\left(\mathrm{gL}^{-1}\right)\end{array}$} & \multicolumn{4}{|c|}{ Alkalizing compound } & \multirow{2}{*}{$\begin{array}{l}\text { Recirculation } \\
\text { ratio }\end{array}$} \\
\hline & & & Chemical & $\begin{array}{l}\text { Dosage } \\
\text { ( } \mathrm{g} \mathrm{g}^{-1} \mathrm{COD}- \\
\text { vinasse) }\end{array}$ & $\begin{array}{l}\text { Mass flow } \\
\text { rate }\left(\mathrm{kg} \mathrm{h}^{-1}\right)^{\mathrm{a}}\end{array}$ & $\begin{array}{l}\text { Application } \\
\text { period (days) }\end{array}$ & \\
\hline SP-NaHCO 3 & No & 28.3 & $\mathrm{NaHCO}_{3}$ & 0.36 & 3908.37 & 232 & - \\
\hline $\mathrm{SP}-\mathrm{NaOH}$ & No & 28.3 & $\mathrm{NaOH}$ & $4 \times 10^{-3}$ & 43.43 & 232 & - \\
\hline SP-NaHCO $3 /$ REC & No & 28.3 & $\mathrm{NaHCO}_{3}$ & 0.36 & 3908.37 & 50 & 15 \\
\hline SP-NaOH/REC & No & 28.3 & $\mathrm{NaOH}$ & $4 \times 10^{-3}$ & 43.43 & 50 & 15 \\
\hline SP-REC & No & 28.3 & - & - & - & - & 15 \\
\hline TP-NaHCO 3 & Yes & $22.3^{b}$ & $\mathrm{NaHCO}_{3}$ & 0.28 & 2395.36 & 232 & - \\
\hline TP-NaOH & Yes & $22.3^{\mathrm{b}}$ & $\mathrm{NaOH}$ & $4 \times 10^{-3}$ & 34.22 & 232 & _- \\
\hline TP-NaHCO $3 /$ REC & Yes & $22.3^{\mathrm{b}}$ & $\mathrm{NaHCO}_{3}$ & 0.28 & 2395.36 & 50 & 15 \\
\hline TP-NaOH/REC & Yes & $22.3^{\mathrm{b}}$ & $\mathrm{NaOH}$ & $4 \times 10^{-3}$ & 34.22 & 50 & 15 \\
\hline TP-REC & Yes & $22.3^{\mathrm{b}}$ & - & - & - & - & 15 \\
\hline
\end{tabular}

Notes: a Calculated based on a vinasse flow rate of $9,207.0 \mathrm{~m}^{3} \mathrm{~d}^{-1}\left(383.62 \mathrm{~m}^{3} \mathrm{~h}^{-1}\right)$; ' Includes organic matter removal during the pre-acidification step $(21.2 \%$, Table 1). $\mathrm{SP}=$ single-phase; $\mathrm{TP}=$ two = phase.

$\left(\mathrm{gL}^{-1}\right.$ or $\mathrm{kg} \mathrm{m}^{-3}$ ) prior to and after the methanogenic phase, respectively. Values of VFR, COD, ER $R_{\mathrm{COD}}, \mathrm{MY}$ and $f_{\mathrm{CH} 4}$ are presented in Table 1. Biogas production was affected only by phase separation; the alkalizing strategy was assumed to not affect biogas flow rate.

$\mathrm{BFR}=\frac{\mathrm{VFR} \cdot \mathrm{COD} \cdot E R_{\mathrm{COD}} \cdot \mathrm{MY}}{f_{\mathrm{CH} 4}}$

$E R_{C O D}=\frac{C O D_{\text {influent }}-C O D_{\text {effluent }}}{C O D_{\text {influent }}}$

The calculated operating parameters for the designed reactors included the OLR (kg-COD m ${ }^{-3}$ day $\left.^{-1}\right)$ and the hydraulic retention time (HRT, h), as shown in Eqs. (3) and (4), respectively, where COD, VFR and $V_{\text {reactor, }}$, respectively, represent the vinasse $\mathrm{COD}\left(\mathrm{gL}^{-1}\right.$ or $\left.\mathrm{kg} \mathrm{m}^{-3}\right)$, the vinasse flow rate $\left(\mathrm{m}^{3} \mathrm{~h}^{-1}\right)$ and the calculated reactor volume $\left(\mathrm{m}^{3}\right)$.

$\mathrm{OLR}=\frac{\mathrm{COD} \cdot \mathrm{VFR}}{\mathrm{V}_{\text {reactor }}}$

$\mathrm{HRT}=\frac{\mathrm{V}_{\text {reactor }} \cdot 24}{\mathrm{VFR}}$

The installed power capacity (IPC, MW) of an ICE-based power plant and the total amount of electricity (EEL, MWh) produced from biogas were calculated according to Eqs. (5) and (6), respectively, where BFR, LHV, $\eta$ and HVP, respectively, represent the biogas flow rate $\left(\mathrm{Nm}^{3} \mathrm{~h}^{-1}\right)$, the lower heating value of the biogas $\left(\mathrm{MJ} \mathrm{Nm}^{-3}\right)$, the electric conversion efficiency of ICE (dimensionless) and the harvesting period (232 days). The LHV was estimated based on the $\mathrm{CH}_{4}$ content in the biogas streams (Walsh et al., 1988), and the estimated values were found to be 23.8 and $20.0 \mathrm{MJ} \mathrm{Nm}^{-3}$ for the two- $\left(\mathrm{f}_{\mathrm{CH} 4}=70.0 \%\right.$-Fuess et al., 2017) and single-phase $\left(\mathrm{f}_{\mathrm{CH} 4}=58.4 \%\right.$-Ferraz et al., 2016) processes, respectively. A conversion efficiency of $43 \%$ was considered for the electricity production from biogas, regardless of the LHV, based on technical specifications of the ICE model J620 GS-F12 (GE Jenbacher $\mathrm{GmbH} \& \mathrm{Co}$. OHG, Jenbach, Austria).

$I P C=\frac{B F R \cdot L H V \cdot \eta}{3600}$
$E E L=I P C \cdot H V P \cdot 24$

\subsection{Economic estimates: capital, operating, biogas and electricity costs}

Capital costs for the AD plants were estimated based on the construction of the reactors and equalization tanks and the acquisition of equipment, such as pumps and gas meters. Installation costs (i.e., mechanical, hydraulic, electric and automation systems) were set to $20 \%$ of the investments with civil engineering works and equipment. Table 3 compiles additional assumptions for the economic estimates, including capital costs for the power plant and $\mathrm{H}_{2} \mathrm{~S}$ removal system, operating costs of the plants, and costs associated with the acquisition of electricity and chemicals $\left(\mathrm{NaHCO}_{3}\right.$ and $\left.\mathrm{NaOH}\right)$. The operating costs included the maintenance of the $\mathrm{AD}$ power plants (including the $\mathrm{H}_{2} \mathrm{~S}$ removal process through the microaeration of the biogas-Muñoz et al., 2015) and annual chemical and electricity costs. The biogas production costs (BPC, USD Nm${ }^{-3}$ ) were obtained from the ratio of the annual operating costs of the AD plant (USD) to the annual biogas production $\left(\mathrm{Nm}^{3}\right)$ in each scenario, according to Eq. (7). The electricity production costs (EPC, USD $\mathrm{MWh}^{-1}$ ) were obtained by dividing the annual operating costs of the $A D$ and power plants (USD) by the annual electricity production (MWh; see Eq. (8)). Overall, these investment and operating costs, raw chemical prices and electricity costs were based on December 2015 values at a conversion rate of USD 0.26 per Brazilian Real.

$B P C=\frac{\text { Annual operating cost }(A D)}{\text { Annual biogas production }}$

$E P C=\frac{\text { Annual operating cost }(A D+\text { power plant })}{\text { Annual electricity production }}$

\section{Results and discussion}

\subsection{AD plants: operation detailing and investment} costs

The properties of the equipment and installations (tanks and reactors) for the two- and single-phase $\mathrm{AD}$ systems are summarized in Tables 4 and 5 , respectively, and include 
Table 3 - Basic input data and assumptions used in the economic estimates.

Economic assumptions

Capital costs

Operating costs

Electricity cost

Chemical costs

\author{
Power plant (internal combustion engine): USD $1705.12 \mathrm{~kW}^{-1}$ \\ $\mathrm{H}_{2} \mathrm{~S}$ removal (microaeration): USD 20,797.40 \\ $2.5 \%$ of the investment costs \\ USD $37.96 \mathrm{MWh}^{-1}$ \\ $\mathrm{NaHCO}_{3}$ : USD $0.92 \mathrm{~kg}^{-1}$ \\ $\mathrm{NaOH}$ : USD $0.53 \mathrm{~kg}^{-1}$
}

Reference

EPA (2015)

Muñoz et al. (2015)

Nogueira et al. (2015)

EPE (2014)

Química e Derivados (2015)

Química e Derivados (2015) data on unit capacity, quantity and total costs. In the twophase scheme (Appendix A-Supplementary data), sugarcane vinasse is initially directed to equalization tanks TQ-01A/B/C and is then pumped into three fixed-bed reactors (APBRs) operated in parallel (RE-01A/B/C). The $\mathrm{pH}$ of the raw vinasse is not adjusted because biohydrogen is not recovered. The acidified vinasse is collected in the equalization tank TQ-02A, where an alkalizing compound is applied to adjust the solution $\mathrm{pH} /$ alkalinity. A centrifugal pump is used to recycle the acidified vinasse in TQ-02A to optimize the use of chemicals. Finally, vinasse is distributed to five methanogenic structuredbed reactors (ASTBRs) and is then directed to the sugarcane crop after the organic polluting load is removed. Biogas streams are collected from the headspace of each reactor and directed to the engines. For scenarios with effluent recirculation, a centrifugal pump is coupled to each methanogenic reactor. Table 6 lists the dimensions and operating parameters of the equalization tanks and reactors for the two-phase AD scheme.

For the single-phase $\mathrm{AD}$ plant (Appendix B-Supplementary data), vinasse is initially equalized in tanks TQ-01A/B and is then directed to tank TQ-01C for pH/alkalinity adjustment. A centrifugal pump also recycles vinasse in TQ01C to optimize chemical use. Vinasse is pumped into six methanogenic reactors (ASTBRs) (RE-02A/B/C/D/E/F) and is then directed to the sugarcane crop. Compared with the two-phase layout, an additional methanogenic reactor is required to guarantee an OLR similar to the optimal value $\left(25 \mathrm{~kg}\right.$-COD m $\left.\mathrm{m}^{-3} \mathrm{~d}^{-1}\right)$. Biogas streams are collected from the headspace of each reactor and directed to the engines. For scenarios with effluent recirculation, a centrifugal pump is also coupled to each methanogenic reactor. The dimensions and operating parameters of the equalization tanks and reactors for the single-phase $\mathrm{AD}$ plant are also listed in Table 6 .

Phase separation resulted in approximately $60 \%$ higher investment costs compared with single-phase AD schemes (USD 10.16 vs. 6.24 million and USD 10.45 vs. 6.52 million, respectively, for schemes without and with effluent recirculation; Tables 4 and 5). The primary expenses were associated with the construction of the reactors and equalization tanks. Despite the lower costs associated with the installation of methanogenic reactors in the two-phase plants (USD 3.07 vs. 3.69 million-Tables 4 and 5), the installation of an additional equalization tank to collect the acidified vinasse resulted in slightly higher costs for civil engineering works in such schemes (USD 4.10 million, Table 4). Effluent recirculation slightly increased the investment costs by approximately 3.0 and $4.5 \%$, respectively, in the two- and single-phase $\mathrm{AD}$ plants. With respect to the power plants, investment costs in twophase AD layouts resulted in higher values (USD 13.17 vs. 10.74 million) because the higher energetic potential of the biogas required a larger set of ICEs.

\subsection{Alkalizing strategies: impacts on biogas and electricity production costs}

The estimated biogas and electricity production costs in the single- and two-phase $A D$ plants are shown in Fig. 2a-b, whereas the operating costs for the $\mathrm{AD}$-power plants in each scenario considered are presented in Fig. 3a-d. The contribution of the costs associated with plant maintenance and of the acquisition of chemicals and electricity to the total costs is detailed in Fig. 3a-d. An overall analysis indicated that phase separation reduced biogas production costs in the scenarios based on the application of $\mathrm{NaHCO}_{3}$ (from 1.373 to $0.829 \mathrm{USD} \mathrm{Nm}^{-3}$ and 0.325 to $0.209 \mathrm{USD} \mathrm{Nm}^{-3}$ for systems without and with effluent recycle, respectively; Fig. 2a). Negligible differences were observed for $\mathrm{NaOH}$ application. Negligible differences were also observed in scenarios based on the use of effluent recycling as the sole alkalizing strategy for methanogenic reactors. In addition to the energetic benefits previously reported in experimental studies (Ferraz et al., 2016; Nasr et al., 2012), the results obtained herein show that phase separation achieves economic benefits for AD plants. The production costs of biogas in such cases were at least similar to the costs determined for the single-phase schemes despite the higher capital and maintenance costs. This was due to the lower chemical dosages used in the twophase processes, especially $\mathrm{NaHCO}_{3}$ (0.28 vs. 0.36 g- $\mathrm{NaHCO}_{3}$ $\mathrm{g}^{-1} \mathrm{COD}$-vinasse, Table 2). Furthermore, the higher electricity costs due to the operation of the acidogenic phase were minimal (Fig. 3a-b).

With respect to the application of $\mathrm{NaHCO}_{3}$, the biogas production costs were significantly higher compared with the use of $\mathrm{NaOH}$ (Fig. 2a), regardless of phase separation and effluent recirculation (Fig. 3a-b), even though the $\mathrm{NaHCO}_{3}$ dosages considered in this study were lower compared with the values reported in the literature for $\mathrm{AD}$ systems treating sugarcane vinasse, e.g., 0.5 g- $\mathrm{NaHCO}_{3} \mathrm{~g}^{-1} \mathrm{COD}$-vinasse (Harada et al., 1996), 0.4-1.2 g- $\mathrm{NaHCO}_{3} \mathrm{~g}^{-1} \mathrm{COD}$-vinasse (Döll and Foresti, 2010), and 1.0 g- $\mathrm{NaHCO}_{3} \mathrm{~g}^{-1} \mathrm{COD}$-vinasse (Siqueira et al., 2013). Future studies would need to optimize the use of $\mathrm{NaHCO}_{3}$ as the alkalizing compound in AD systems applied to vinasse by focusing on the attainment of economically more competitive treatment plants. Theoretically, the use of $\mathrm{NaHCO}_{3}$ provides better conditions for methanogens than strongly alkaline compounds, such as $\mathrm{NaOH}$, because systems are externally buffered, i.e., the stability of the reactors do not exclusively rely on the alkalinity generated in loco from acetate consumption (Reaction (1)).

$\mathrm{CH}_{3} \mathrm{COO}^{-}+\mathrm{H}_{2} \mathrm{O} \rightarrow \mathrm{HCO}_{3}^{-}+\mathrm{CH}_{4}$

The biogas production costs calculated for dosing with $\mathrm{NaOH}$ in the anaerobic reactors $\left(0.020-0.035 \mathrm{USD} \mathrm{Nm}^{-3}\right.$, Fig. 2a) and for effluent recirculation-only (0.031-0.037 USD Nm${ }^{-3}$, Fig. 2a) strategies were quite similar, regardless of phase sep- 
Table 4 - Details of civil works and equipment for implementing two-phase biodigestion plants for the treatment of vinasse in sugarcane biorefineries.

\begin{tabular}{|c|c|c|c|c|c|c|c|}
\hline \multirow[t]{2}{*}{ Process step } & \multirow[t]{2}{*}{ Civil work/equipment } & \multirow[t]{2}{*}{ Identification ${ }^{a}$} & \multirow[t]{2}{*}{ Material } & \multirow[t]{2}{*}{ Capacity } & \multirow[t]{2}{*}{ Quantity } & \multicolumn{2}{|c|}{ Cost (USD) } \\
\hline & & & & & & Unit & Total \\
\hline Equalization & Equalization tank & TQ-01 & Reinforced concrete & $1051.25 \mathrm{~m}^{3}$ & 3 & $355,322.50$ & $1,065,967.50$ \\
\hline \multirow[t]{7}{*}{ Acidogenic phase } & Online $\mathrm{pH}$ meter & $\mathrm{pH}$ & - & - & 1 & 3900.00 & 3900.00 \\
\hline & Centrifugal pump (reactor feeding) & CP-01 & - & $127.87 \mathrm{~m}^{3} \mathrm{~h}^{-1}$ & 4 & 4468.80 & $17,875.19$ \\
\hline & APBR & RE-01 & Reinforced concrete & $1820.00 \mathrm{~m}^{3}$ & 3 & $615,160.00$ & $1,845,480.00$ \\
\hline & Support material—01 & LDPE & LDPE & - & $1875.90 \mathrm{~m}^{3}$ & $520.00^{\mathrm{b}}$ & $975,468.00$ \\
\hline & Screen for support material retaining & $\mathrm{sC}$ & Stainless steel & - & $1560.00 \mathrm{~m}^{2}$ & $52.00^{c}$ & $81,120.00$ \\
\hline & Water seal & WS-01 & Stainless steel & - & 3 & 2080.00 & 6240.00 \\
\hline & Gas meter & BFR & - & - & 1 & 5200.00 & 5200.00 \\
\hline \multirow[t]{11}{*}{ Methanogenic phase } & Equalization tank & TQ-02 & Reinforced concrete & $3062.46 \mathrm{~m}^{3}$ & 1 & $1,035,111.48$ & $1,035,111.48$ \\
\hline & Centrifugal pump (recirculation-TQ-02) & CP-02 & - & - & 2 & $2,681,28$ & 5362.56 \\
\hline & Online $\mathrm{pH}$ meter & $\mathrm{pH}$ & - & - & 1 & 3900.00 & 3900.00 \\
\hline & Dosing pump & DP-02 & - & - & 2 & 1300.00 & 2600.00 \\
\hline & Centrifugal pump (reactor feeding) & CP-03 & - & $76.72 \mathrm{~m}^{3} \mathrm{~h}^{-1}$ & 6 & 2681.28 & $16,087.67$ \\
\hline & ASTBR & RE-02 & Reinforced concrete & $1820.00 \mathrm{~m}^{3}$ & 5 & $615,160.00$ & $3,075,800.00$ \\
\hline & Centrifugal pump (effluent recirculation) & $\mathrm{CP}-04$ & - & $1150.80 \mathrm{~m}^{3} \mathrm{~h}^{-1}$ & 6 & $40,216.55$ & $241,299.28$ \\
\hline & Support material-02 & PU & Polyurethane & - & $338.00 \mathrm{~m}^{3}$ & $520.00^{\mathrm{b}}$ & $175,760.00$ \\
\hline & Screen for support material retaining & $\mathrm{SC}$ & Stainless steel & - & $2.600,00 \mathrm{~m}^{2}$ & $52.00^{c}$ & $135,200.00$ \\
\hline & Water seal & WS-02 & Stainless steel & - & 5 & 2080.00 & $10,400.00$ \\
\hline & Gas meter & BFR & - & - & 1 & 5200.00 & 5200.00 \\
\hline $\begin{array}{l}\text { Total investment }{ }^{\mathrm{d}} \\
\text { (without effluent } \\
\text { recirculation) }\end{array}$ & & & & & & & $10,160,006.88$ \\
\hline $\begin{array}{l}\text { Total investment }{ }^{\mathrm{d}} \text { (with } \\
\text { effluent recirculation) }\end{array}$ & & & & & & & $10,449,566.02$ \\
\hline
\end{tabular}




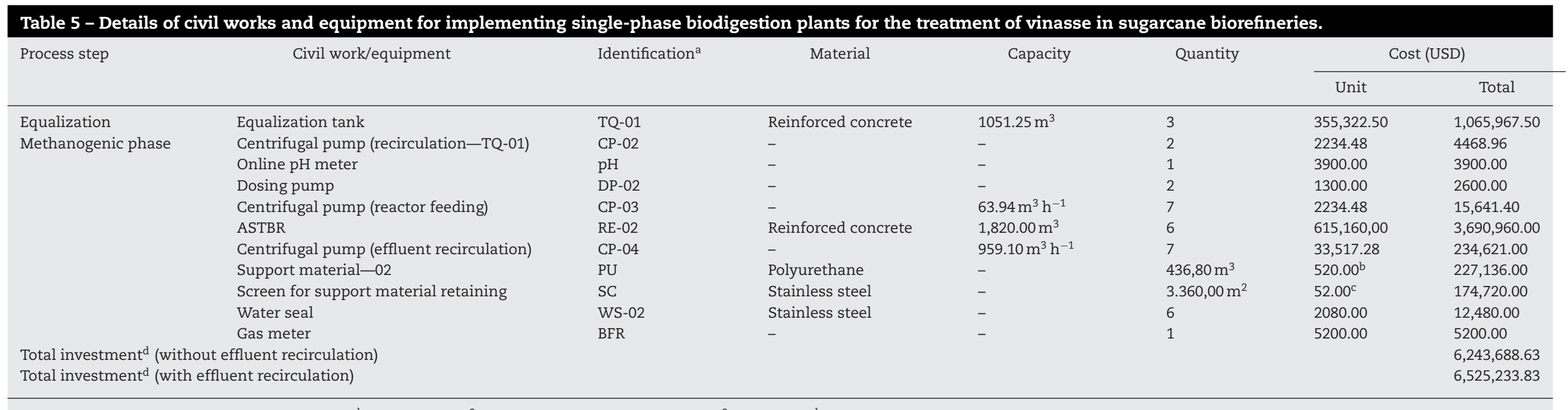

Notes: a See Appendix B-Supplementary data; ${ }^{b}$ Per volume $\left(\mathrm{m}^{3}\right)$ of support material; ${ }^{\mathrm{c} P e r}$ area $\left(\mathrm{m}^{2}\right)$ of screen; ${ }^{\mathrm{d}}$ Includes installation costs with mechanical, hydraulic, electrical, and automation systems.

\begin{tabular}{|c|c|c|c|c|c|c|c|}
\hline \multirow[t]{2}{*}{ Unit } & & \multirow[t]{2}{*}{ Identification $^{\mathrm{a}}$} & \multicolumn{5}{|c|}{ Dimension and operating characteristics } \\
\hline & & & Total volume $\left(\mathrm{m}^{3}\right)$ & Working volume ${ }^{\mathrm{b}}\left(\mathrm{m}^{3}\right)$ & $\mathrm{W} \times \mathrm{L} \times \mathrm{Ht}(\mathrm{m})^{\mathrm{c}}$ & OLR $\left(\mathrm{kg}^{\left.-C O D ~ \mathrm{~m}^{-3} \mathrm{~d}^{-1}\right)}\right.$ & HRT (h) \\
\hline \multirow[t]{4}{*}{ Two-phase AD plant } & Equalization tank & $\mathrm{TQ}-01 \mathrm{~A} / \mathrm{B} / \mathrm{C}$ & 1156.37 & $1051.25^{d}$ & $14.5 \times 14.5 \times 5.5$ & - & 8.2 \\
\hline & Acidogenic reactor (APBR) & $\mathrm{RE}-01 \mathrm{~A} / \mathrm{B} / \mathrm{C}$ & 1820.00 & $1064.70^{\mathrm{e}}$ & $13.0 \times 20.0 \times 7.0$ & 81.6 & 8.3 \\
\hline & Equalization tank & TQ-02A & 3363.75 & $3105.00^{f}$ & $22.5 \times 23.0 \times 6.5$ & - & 8.1 \\
\hline & Methanogenic reactor (ASTBR) & $\mathrm{RE}-02 \mathrm{~A} / \mathrm{B} / \mathrm{C} / \mathrm{D} / \mathrm{E}$ & 1820.00 & $1,622.40^{\mathrm{e}}$ & $13.0 \times 20.0 \times 7.0$ & 25.3 & 21.1 \\
\hline \multirow[t]{2}{*}{ Single-phase AD plant } & Equalization tank & $\mathrm{TQ}-01 \mathrm{~A} / \mathrm{B} / \mathrm{C}$ & 1156.37 & $1051.25^{\mathrm{d}}$ & $14.5 \times 14.5 \times 5.5$ & - & 8.2 \\
\hline & Methanogenic reactor (ASTBR) & $\mathrm{RE}-02 \mathrm{~A} / \mathrm{B} / \mathrm{C} / \mathrm{D} / \mathrm{E} / \mathrm{F}$ & 1960.00 & $1747.20^{\mathrm{e}}$ & $14.0 \times 20.0 \times 7.0$ & 24.8 & 27.3 \\
\hline
\end{tabular}




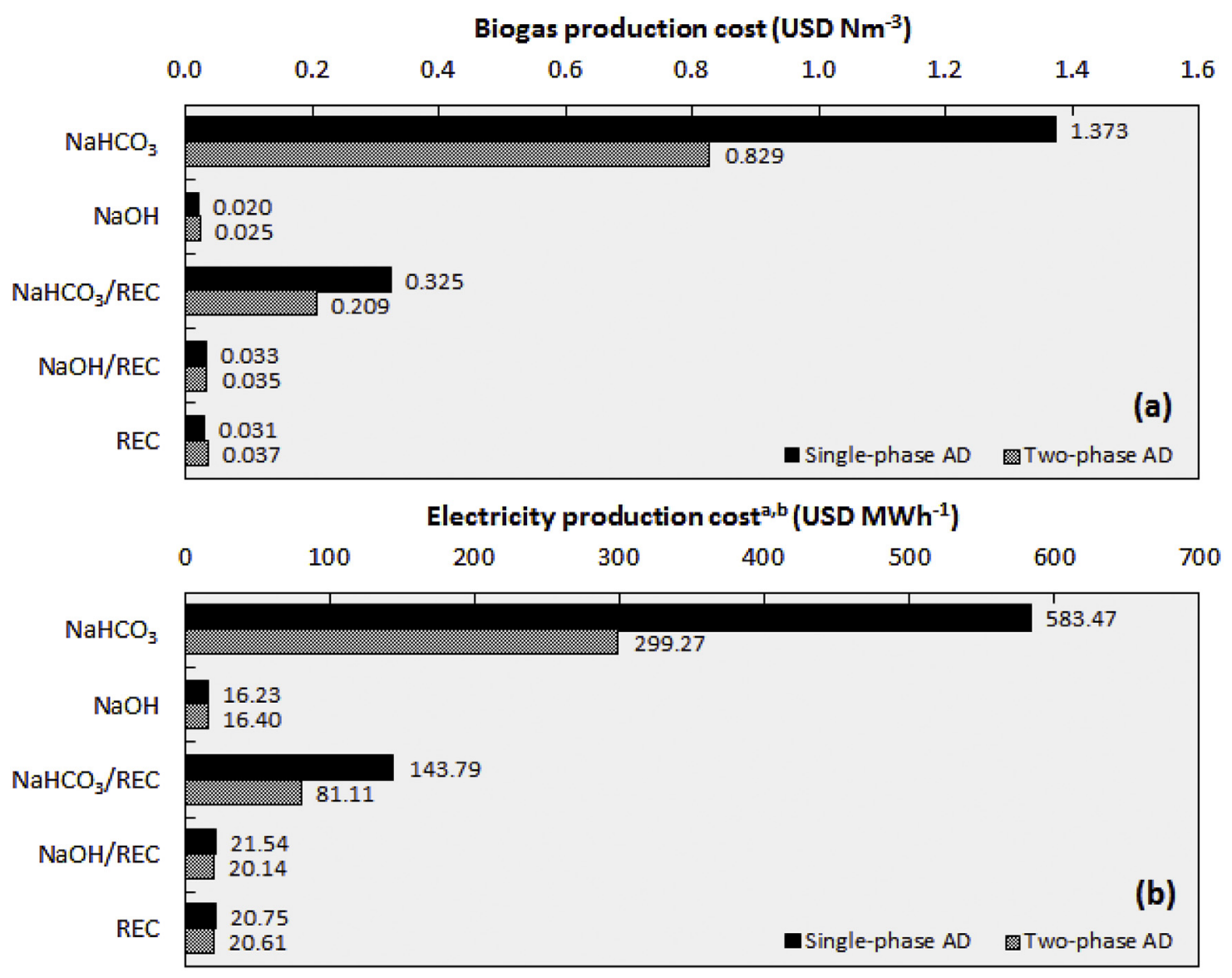

Fig. 2 - Biogas (a) and electricity (b) production costs for full-scale AD plants treating sugarcane vinasse. Notes: ${ }^{\mathrm{a}} \mathrm{LHV}$ of biogas from two- and single-phase processes were 23.8 and $20.0 \mathrm{MJ} \mathrm{Nm}^{-3}$, respectively, based on Walsh et al. (1988); ${ }^{b}$ Electric efficiency conversion set as $43 \%$, based on technical specifications of the internal combustion engine model $\mathbf{J} 620$ GS-F12 (GE Jenbacher GmbH \& Co. OHG, Jenbach, Austria).

aration. Regarding the operating costs (Fig. 3c-d), the lower (or null) chemical costs $(\mathrm{NaOH})$ in systems with effluent recirculation were offset by the higher electricity costs, which accounted for the similar overall costs. Although the application of $\mathrm{NaOH}$ does not provide the same buffer control to the $\mathrm{AD}$ systems as $\mathrm{NaHCO}_{3}$, as $\mathrm{NaOH}$ only acts as a strong neutralizing agent by releasing hydroxide ions $\left(\mathrm{OH}^{-}\right)$(Lozada et al., 2008) (Reaction (2)), good treatment performances have been previously associated with its use in AD systems applied to sugarcane vinasse. In particular, Souza et al. (1992) reported COD removal levels above $70 \%$ and a methane yield of $0.310 \mathrm{Nm}^{3}-\mathrm{CH}_{4} \mathrm{~kg}^{-1} \mathrm{COD}$-removed when applying low $\mathrm{NaOH}$ dosages $\left(4 \times 10^{-3} \mathrm{~g}\right.$-NaOH g ${ }^{-1} \mathrm{COD}$-vinasse) to a thermophilic $\left(55^{\circ} \mathrm{C}\right)$, pilot-scale $\left(75 \mathrm{~m}^{3}\right)$, single-phase granular sludge reactor with an OLR of $26.5 \mathrm{~kg}$-COD m $\mathrm{m}^{-3}$ day $^{-1}$. These results indicated that $\mathrm{NaOH}$ dosing in full-scale $\mathrm{AD}$ plants for vinasse may be a feasible option because both technical and economic requirements could be met.

$\mathrm{NaOH} \rightarrow \mathrm{Na}^{+}+\mathrm{OH}^{-}$

In terms of the sole application of effluent recirculation, the experience with two fixed-bed full-scale $\left(4500 \mathrm{~m}^{3}\right.$ each) digesters reported by Nandy et al. (2002) also characterizes such an alkalizing strategy as an attractive option to sugarcane biorefineries. In this case, the authors indicated a successful operation (COD and BOD removals close to 70 and $80 \%$, respectively, OLR of $10 \mathrm{~kg}$-COD $\mathrm{m}^{-3}$ day $^{-1}$ ) by applying effluent recirculation ratios of approximately 20 in each reactor, to recycle the alkalinity resulting from methanogenesis. It should be observed, however, that for higher OLRs, such as that reported in the systems used as reference herein $(25 \mathrm{~kg}$ COD m ${ }^{-3}$ day $^{-1}$; Ferraz et al., 2016; Fuess et al., 2017; or 26.5 kg-COD m ${ }^{-3}$ day $^{-1}$; Souza et al., 1992), dosing a neutralizing/alkalizing compound at least during the start-up period may be recommended, in an effort to avoid problems with imbalance due to the eventual rapid acidification of vinasse.

Similar patterns were obtained for the electricity production costs (Fig. 2b). Considerably higher values were observed for the use of $\mathrm{NaHCO}_{3}$ than for the scenarios using $\mathrm{NaOH}$ and/or effluent recirculation. The electricity costs associated with $\mathrm{NaOH}$ dosing and/or recirculation (Fig. 2b) were 1.8- (21.54 USD $\mathrm{MWh}^{-1}, \mathrm{SP}-\mathrm{NaOH} / \mathrm{REC}$ ) to 2.3-fold (16.23 USD $\mathrm{MWh}^{-1}$, SP-NaOH) lower compared with electricity costs from the grid (37.96 USD MWh ${ }^{-1}$-EPE, 2014). Nogueira et al. (2015) reported biogas production costs in the range of 38.91 to 56.32 USD $\mathrm{MWh}^{-1}$ for smaller-sized sugarcane-based biorefineries $\left(V F R=5000 \mathrm{~m}^{3}\right.$ day $^{-1}$ or $208.3 \mathrm{~m}^{3} \mathrm{~h}^{-1}, \mathrm{CH}_{4}$ content in biogas $=60 \%$ ). These differences most likely resulted from the different power plant sizes. The estimated installed capacity for the power plants coupled to the single- and two-phase AD plants in this study were 6.3 and $7.7 \mathrm{MW}$, respectively, whereas Nogueira et al. (2015) reported a capacity of 3.1 MW.

The operating costs and the revenue from the sale of the electricity produced from the biogas for the AD plants of each scenario were used to estimate the financial return of the projects for a lifetime of 25 years (Fig. 4). The per-unit revenue of the electricity produced from biogas was equal to the cost 


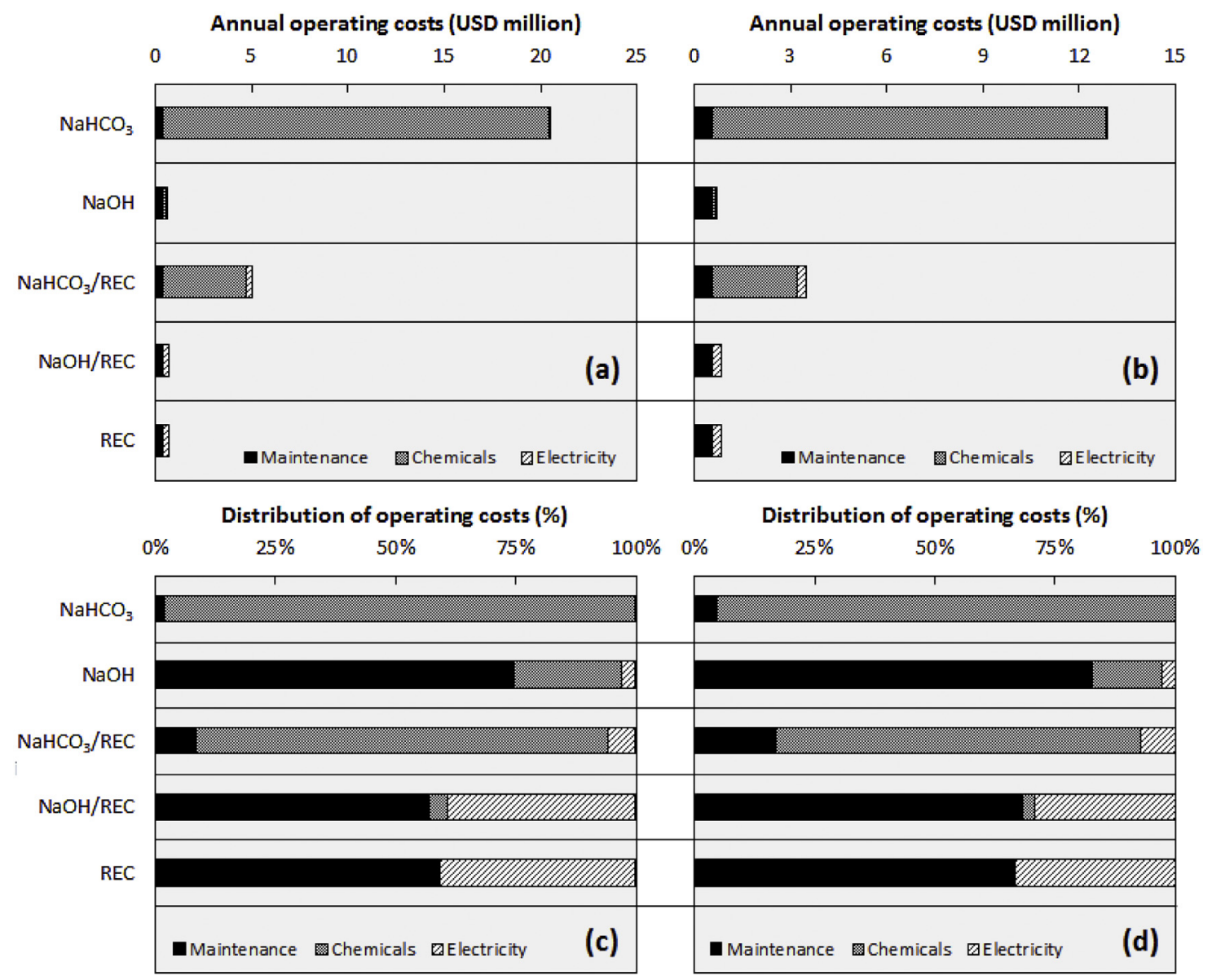

Fig. 3 - Annual operating costs for AD-power plants with (a) single- and (b) two-phase AD schemes, and distribution of operating costs for AD-power plants with (c) single- and (d) two-phase AD schemes. Note: Electricity costs calculated from the operating of dosing $(0.5 \mathrm{CV})$ and centrifugal pumps (respectively, 15 and $300 \mathrm{CV}$ for reactor feeding and effluent recirculation).

of the electricity purchased from the grid, i.e., USD 37.96 per MWh (EPE, 2014). The application of $\mathrm{NaHCO}_{3}$ during the entire operating period of the systems resulted in economic losses of over USD 400 million in the single-phase AD systems and slightly more than USD 200 million in the two-phase schemes (Fig. 4a). These values confirmed the economic unfeasibility of this alkalizing strategy. The combined $\mathrm{NaHCO}_{3}$ dosing and effluent recirculation strategies (Fig. 4c) resulted in different results depending on the type of the $\mathrm{AD}$ plant used: an accumulated loss of approximately USD 50 million was calculated for single-phase schemes and a net profit of USD 5.5 million in the two-phase systems was reported. However, the payback of the investments for the two-phase systems would only be observed after 32.0 years of operation, which rendered the two-phase systems unfeasible due to the considered 25year lifetime. With respect to the other alkalizing strategies, i.e., $\mathrm{NaOH}$ dosing and/or effluent recirculation only (Fig. 4b, $\mathrm{d}$ and e), favorable scenarios were achieved, with net profits ranging from 58.7 to 63.6 and 70.6 to 75.4 USD million for single- and two-phase AD plants, respectively. In such cases, the estimated investment payback would be observed within 4.1-4.5 (single-phase) and 6.7-6.8 (two-phase) years. This indicated that dosing $\mathrm{NaOH}$ in full-scale $\mathrm{AD}$ systems for sugarcane vinasse was economically feasible. In particular, the relatively similar payback times (Fig. 4b, d, and e) associated with net earnings $18.5-21.1 \%$ higher showed the advantages of twophase AD systems compared with single-phase AD systems.
Finally, the biogas and electricity costs could be reduced by excluding expenditures associated with electricity in the $\mathrm{AD}$ plants because the electric requirements of the pumps could be fully supplied by the power generated from bagasse burning in cogeneration systems. Thermoelectricity production from bagasse reaches approximately $46.2 \mathrm{kWh} \mathrm{TC}^{-1}$ in sugarcane biorefineries, and $21.1 \mathrm{kWh} \mathrm{TC}^{-1}$ of this amount is promptly consumed within the plant (CONAB, 2011). Electricity consumption in $\mathrm{AD}$ plants would then require only $0.11-0.14 \mathrm{kWh}$ $\mathrm{TC}^{-1}$ and $1.67-1.95 \mathrm{kWh} \mathrm{TC}^{-1}$ in schemes without and with effluent recirculation, i.e., demanding less than $8 \%$ of the surplus thermoelectricity $\left(25.1 \mathrm{kWh} \mathrm{TC}^{-1}, \mathrm{CONAB}, 2011\right)$. In terms of biogas and electricity production costs, the most remarkable reductions would be observed for AD schemes that use effluent recirculation (with or without $\mathrm{NaOH}$ dosing) because operating costs would be reduced by over $30 \%$.

\subsection{Outlook: expanding the implications of vinasse alkalinization}

In addition to the economic aspects of dosing $\mathrm{NaHCO}_{3}$ and $\mathrm{NaOH}$ as alkalizing compounds for sugarcane vinasse (see Section 3.2), some environmental implications of the alkalinization process should be considered, in particular regarding the role of sodium ions $\left(\mathrm{Na}^{+}\right)$in soils fertirrigated with biodigested vinasses. $\mathrm{Na}^{+}$ions act as highly dispersive agents, when hydrated, by disrupting soil stable aggregates, which may drastically reduce water infiltration due to the clogging 

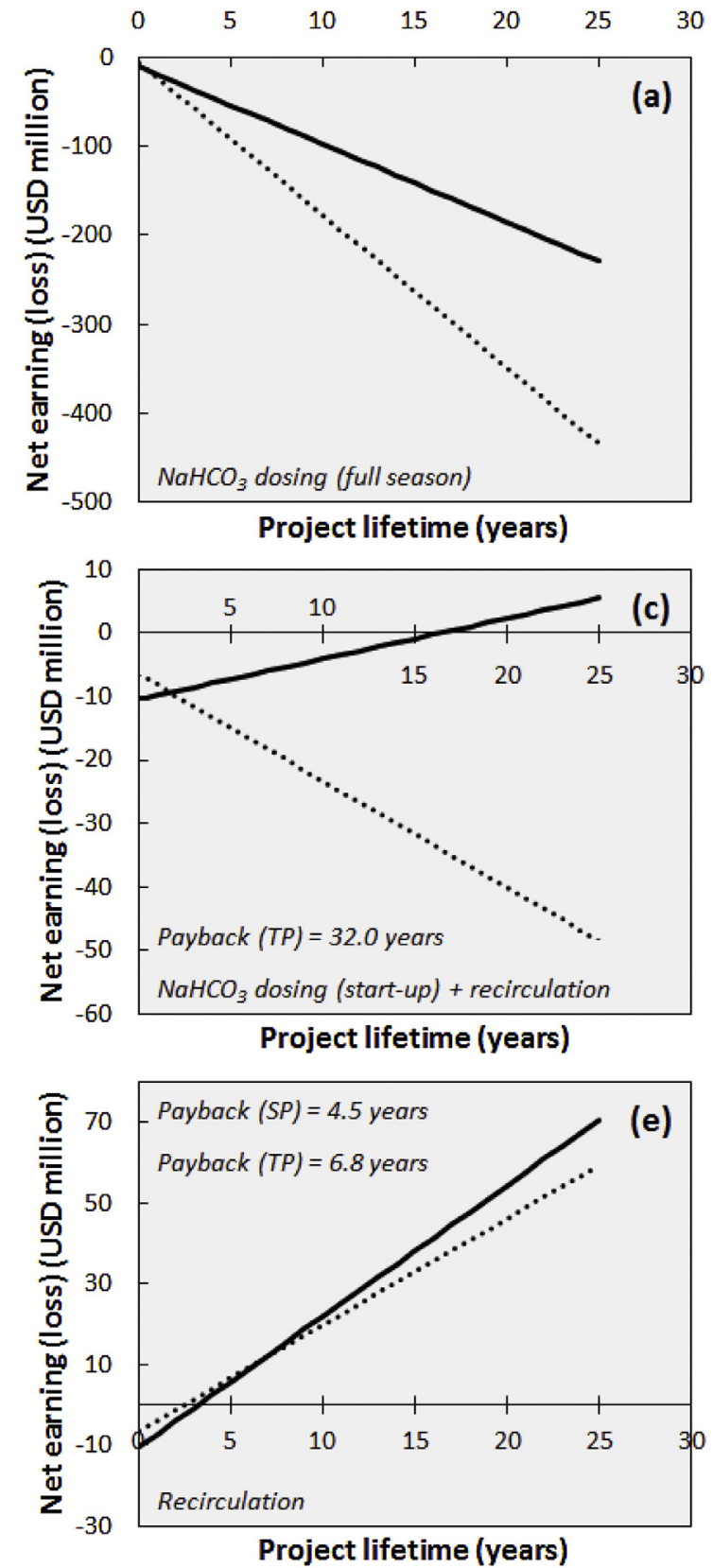
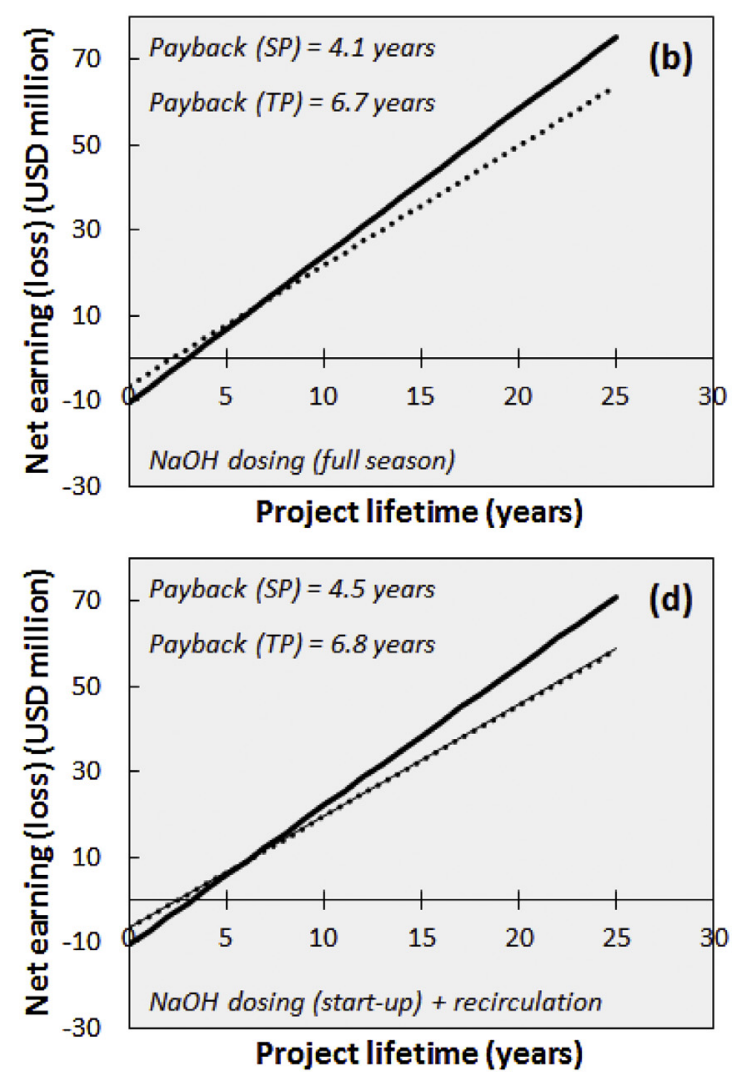

Single-phase (SP) AD

Two-phase (TP) AD

Payback: period of time in which the cumulative net earnings equal the initial investment of the project.

Fig. 4 - Net earnings/losses estimated for the AD plants according to different alkalizing strategies within a project lifetime of 25 years: (a) $\mathrm{NaHCO}_{3}$ dosing (full sugarcane season), (b) $\mathrm{NaOH}$ dosing (full sugarcane season), (c) $\mathrm{NaHCO}_{3}$ dosing (reactor start-up) with effluent recirculation, (d) $\mathrm{NaOH}$ dosing (reactor start-up) with effluent recirculation, and (e) effluent recirculation.

up of soil pores and reduce the productivity of sugarcane fields (Tejada and Gonzalez, 2006; Fuess and Garcia, 2014). The negative effects are observed when the concentrations of $\mathrm{Na}^{+}$are much higher (at least 3-fold) than those of specific bivalent ions, such as calcium and magnesium (WHO, 2006), considering the process of soil sodification.

Although $\mathrm{Na}^{+}$concentrations in sugarcane vinasse are relatively low (50-325 $\mathrm{mg} \mathrm{L}^{-1}$-; Lyra et al., 2003; Mariano et al., 2009; Ferreira et al., 2011; Rolim et al., 2013) compared to other ions, e.g., potassium (1200-4600 $\mathrm{mg} \mathrm{L}^{-1}$-; Prada et al., 1998) and sulfates (600-3730 $\mathrm{mgL}^{-1}$-; Ferreira et al., 2011; Prada et al., 1998), the inputs of $\mathrm{Na}^{+}$ions could result in concentrations of approximately $1800-3400 \mathrm{mg} \mathrm{L}^{-1}$ when using $\mathrm{NaHCO}_{3}$ as the alkalizing compound. These values are at least 2.4- to 5.8-fold higher than the concentrations of calcium $\left(460-740 \mathrm{mg} \mathrm{L}^{-1}\right)$ and magnesium (210-310 $\left.\mathrm{mg} \mathrm{L}^{-1}\right)$ commonly measured in sug- arcane vinasse (Lyra et al., 2003; Mariano et al., 2009; Ferreira et al., 2011; Rolim et al., 2013), in order to increase the risks of soil sodification. Conversely, the use of $\mathrm{NaOH}$ in the considered dosage ( $4 \mathrm{~g} \mathrm{~g}^{-1} \mathrm{COD}$-vinasse-Table 2 ) would only slightly increase $\mathrm{Na}^{+}$levels in vinasse $\left(51.3-65.1 \mathrm{mg} \mathrm{L}^{-1}\right.$, depending on the application of phase separation), most likely leading to null risks of soil sodification when applying the biodigested vinasse into soils.

In summary, the results indicate that using low dosages of chemicals coupled to the recirculation of the effluent may be characterized as the most suitable alternative for the alkalinization of full-scale AD plants on an economic and environmental basis. Nevertheless, further studies on alternative alkalizing strategies for vinasse should still be considered, in an effort to improve both economic and environmental performances of the biodigestion plants. Additional strate- 
gies could include the use of ashes from incinerators (Banks and Lo, 2003; Podmirseg et al., 2013) and the optimization of dosing alternative chemicals (e.g. urea, limestone and caustic potash-KOH). In particular, the use of ashes from bagasse burning in cogeneration systems as complementary alkalizing agents in anaerobic reactors could characterize a cheap alternative to biorefineries, given the possibility to eliminate costs from the purchase of chemicals. This strategy could also improve the management of residues within sugarcane biorefineries, also supplementing vinasse with essential metals.

\section{Concluding remarks}

The results obtained herein highlight the economic feasibility of scaling-up two-phase AD plants in sugarcane-based biorefineries for the treatment of vinasse. Despite the higher capital and operating costs of such schemes, the estimated biogas and electricity production costs are equivalent or lower compared with those of single-phase AD plants, depending on the alkalizing strategy used. $\mathrm{NaHCO}_{3}$ dosing applied to AD systems largely results in unfavorable economic performances. Thus, the best results were obtained using $\mathrm{NaOH}$ dosing with or without effluent recirculation, with electricity costs reaching values 1.8 - to 2.3-fold lower than that of grid electricity. Further experimental studies on the optimization of $\mathrm{NaHCO}_{3}$ are recommended to increase the economic competitiveness of this type of alkalizing strategy in full-scale AD plants.

\section{Acknowledgements}

The authors are grateful for the financial support provided by the São Paulo Research Foundation (Fapesp; grant numbers 2009/15984-0 and 2012/15606-9). The authors are also grateful to the reviewers of Chemical Engineering Research and Design, whose suggestions improved the quality of this study.

\section{Appendix A. Supplementary data}

Supplementary data associated with this article can be found, in the online version, at http://dx.doi.org/10.1016/j.cherd.2017.01.023.

\section{References}

Banks, C.J., Lo, H.M., 2003. Assessing the effects of municipal solid waste incinerator bottom ash on the decomposition of biodegradable waste using a completely mixed anaerobic reactor. Waste Manage. Res. 21 (3), 225-234.

Barrera, E.L., Rosa, E., Spanjers, H., Romero, O., De Meester, S. Dewulf, J., 2016. A comparative assessment of anaerobic digestion power plants as alternative to lagoons for vinasse treatment: life cycle assessment and exergy analysis. J. Clean. Prod. 113, 459-471, http://dx.doi.org/10.1016/j.jclepro.2015.11.095.

Boncz, M.A., Formagini, E.L., Santos, L.S., Marques, R.D., Paulo, P.L., 2012. Application of urea dosing for alkalinity supply during anaerobic digestion of vinasse. Water Sci. Technol. 66 (11), 2453-2460, http://dx.doi.org/10.2166/wst.2012.476.

Bories, A., Raynal, J., Bazile, F., 1988. Anaerobic digestion of high-strength distillery wastewater (cane molasses vinasse) in a fixed-film reactor. Biol. Wastes 23, 251-267, http://dx.doi.org/10.1016/0269-7483(88)90014-6.

Camiloti, P.R., Mockaitis, G., Rodrigues, J.A.D., Damianovic, M.H.R.Z., Foresti, E., Zaiat, M., 2014. Innovative anaerobic bioreactor with fixed-structured bed (ABFSB) for simultaneous sulfate reduction and organic matter removal. J. Chem.
Technol. Biotechnol. 89, 1044-1050, http://dx.doi.org/10.1002/jctb.4199.

Chan, Y.J., Chong, M.F., Law, C.L., Hassell, D.G., 2009. A review on anaerobic-aerobic treatment of industrial and municipal wastewater. Chem. Eng. J. 155, 1-8, http://dx.doi.org/10.1016/j.cej.2009.06.041.

CONAB, 2011. The thermoelectric generation from sugarcane bagasse burning in Brazil: performance analysis for the 2009-2010 harvest. CONAB, Brasília, Brazil, http://www.conab.gov.br/OlalaCMS/uploads/arquivos/ 11_05_05_15_45_40_geracao_termo_baixa_res.pdf. (Accessed 26 May 2015). (in Portuguese).

Costa, F.J.C.B., Rocha, B.B.M., Viana, C.E., Toledo, A.C., 1986. Utilization of vinasse effluents from an anaerobic reactor. Water Sci. Technol. 18 (12), 135-141.

Craveiro, A.M., Soares, H.M., Schmidell, W., 1986. Technical aspects and cost estimations for anaerobic systems treating vinasse and brewery/soft drink wastewaters. Water Sci. Technol. 18 (12), 123-134.

Dias, M.O.S., Maciel Filho, R., Mantelatto, P.E., Cavalett, O., Rossell, C.E.V., Bonomi, A., Leal, M.R.L.V., 2015. Sugarcane processing for ethanol and sugar in Brazil. Environ. Dev. 15, 35-51, http://dx.doi.org/10.1016/j.envdev.2015.03.004.

Döll, M.M.R., Foresti, E., 2010. Effect of the sodium bicarbonate in the treatment of vinasse in AnSBBR operated at 55 and $35^{\circ} \mathrm{C}$. Eng. Sanit. Ambient. 15, 275-282, http://dx.doi.org/10.1590/S1413-41522010000300011 (in Portuguese).

EPA, 2015. Catalog of CHP technologies U.S. Environmental Protection Agency, Combined Heat and Power Partnership, https://www.epa.gov/sites/production/files/2015-07/documents/ catalog_of_chp_technologies.pdf. (Accessed 11 January 2016).

EPE, 2014. 2014 Statistical Yearbook of Electricity-2013 Baseline Year. EPE, Rio de Janeiro, Brazil, http://www.epe.gov.br/ AnuarioEstatisticodeEnergiaEletrica/Anu\%C3\%A1rio\%20Estat \%C3\%ADstico\%20de\%20Energia\%20El\%C3\%A9trica\%202014.pdf. (Accessed 11 January 2016).

Ferraz Jr., A.D.N., Koyama, M.H., Araújo Jr., M.M., Zaiat, M., 2016. Thermophilic anaerobic digestion of raw sugarcane vinasse. Renew. Energy 89, 245-252, http://dx.doi.org/10.1016/j.renene.2015.11.064.

Ferreira, L.F.R., Aguiar, M.M., Messias, T.G., Pompeu, G.B., Lopez, A.M.Q., Silva, D.P., Monteiro, R.T., 2011. Evaluation of sugar-cane vinasse treated with Pleurotus sajor-caju utilizing aquatic organisms as toxicological indicators. Ecotox. Environ. Safe. 74, 132-137, http://dx.doi.org/10.1016/j.ecoenv.2010.08.042.

Fuess, L.T., Garcia, M.L., 2014. Implications of stillage land disposal: a critical review on the impacts of fertigation. J. Environ. Manage. 145, 210-229, http://dx.doi.org/10.1016/j.jenvman.2014.07.003.

Fuess, L.T., Garcia, M.L., 2015. Bioenergy from stillage anaerobic digestion to enhance the energy balance ratio of ethanol production. J. Environ. Manage. 162, 102-114, http://dx.doi.org/10.1016/j.jenvman.2015.07.046.

Fuess, L.T., Kiyuna, L.S.M., Garcia, M.L., Zaiat, M., 2016. Operational strategies for long-term biohydrogen production from sugarcane stillage in continuous acidogenic packed-bed reactor. Int. J. Hydrogen Energy 41, 8132-8145, http://dx.doi.org/10.1016/j.ijhydene.2015.10.143.

Fuess, L.T., Kiyuna, L.S.M., Ferraz Jr., A.D.N., Persinoti, G.F., Squina, F.M., Garcia, M.L., Zaiat, M., 2017. Thermophilic two-phase anaerobic digestion using an innovative fixed-bed reactor for enhanced organic matter removal and bioenergy recovery from sugarcane vinasse. Appl. Energy 189, 480-491, http://dx.doi.org/10.1016/j.apenergy.2016.12.071.

Goyal, S.K., Seth, R., Handa, B.K., 1996. Diphasic fixed-film biomethanation of distillery spentwash. Bioresour. Technol. 56, 239-244, http://dx.doi.org/10.1016/j.biortech.2007.06.060.

Hallenbeck, P.C., 2009. Fermentative hydrogen production: principles, progress, and prognosis. Int. J. Hydrogen Energy 34, 7379-7389, http://dx.doi.org/10.1016/j.ijhydene.2008.12.080. 
Harada, H., Uemura, S., Chen, A.C., Jayadevan, J., 1996. Anaerobic treatment of a recalcitrant distillery wastewater by a thermophilic UASB reactor. Bioresour. Technol. 55, 215-221, http://dx.doi.org/10.1016/0960-8524(96)00003-X.

Ke, S., Shi, Z., Fang, H.H.P., 2005. Applications of two-phase anaerobic degradation in industrial wastewater treatment. Int. J. Environ. Pollut. 23, 65-80, http://dx.doi.org/10.1504/IJEP.2005.006396.

Kumar, G.S., Gupta, S.K., Singh, G., 2007. Biodegration of distillery spent wash in anaerobic hybrid reactor. Water Res. 41, 721-730, http://dx.doi.org/10.1016/j.watres.2006.11.039.

Lozada, P.T., Vidal, A.P., Cajigas, A.A., Otero, A.M., Gonzalez, M., 2008. Selección de acondicionadores químicos para el tratamiento anaerobio de aguas residuales del proceso de extracción de almidón de yuca. Ing. Recur. Nat. Ambient. 7 , $66-74$.

Lyra, M.R.C.C., Rolim, M.M., Silva, J.A.A., 2003. Toposequence of soils fertigated with stillage: contribution towards the quality of ground water table. R. Bras. Eng. Agric. Ambient. 7, 525-532, http://dx.doi.org/10.1590/S1415-43662003000300020 (in Portuguese).

Mariano, A.P., Crivelaro, S.H.R., Angelis, D.F., Bonotto, D.M., 2009. The use of vinasse as an amendment to ex-situ bioremediation of soil and groundwater contaminated with diesel oil. Braz. Arch. Biol. Technol. 52, 1043-1055, http://dx.doi.org/10.1590/S1516-89132009000400030.

Moraes, B.S., Junqueira, T.L., Pavanello, L.G., Cavalett, O., Mantelatto, P.E., Bonomi, A., Zaiat, M., 2014. Anaerobic digestion of vinasse from sugarcane biorefineries in Brazil from energy, environmental, and economic perspectives: profit or expense? Appl. Energy 113, 825-835, http://dx.doi.org/10.1016/j.apenergy.2013.07.018.

Moraes, B.S., Zaiat, M., Bonomi, A., 2015. Anaerobic digestion of vinasse from sugarcane ethanol production in Brazil: challenges and perspectives. Renew. Sustain. Energy Rev. 44, 888-903, http://dx.doi.org/10.1016/j.rser.2015.01.023.

Muñoz, R., Meier, L., Diaz, I., Jeison, D., 2015. A critical review on the state-of-the-art of physical/chemical and biological technologies for an integral biogas upgrading. Rev. Environ. Sci. Biotechnol. 14, 727-759, http://dx.doi.org/10.1007/s11157-015-9379-1.

Nandy, T., Shastry, S., Kaul, S.N., 2002. Wastewater management in a cane molasses distillery involving bioresource recovery. J. Environ. Manage. 65, 25-38, http://dx.doi.org/10.1006/jema.2001.0505.

Nasr, N., Elbeshbishy, E., Hafez, H., Nakhla, G., El Naggar, M.H., 2012. Comparative assessment of single-stage and two-stage anaerobic digestion for the treatment of thin vinasse. Bioresour. Technol. 111, 122-126, http://dx.doi.org/10.1016/j.biortech.2012.02.019.

Nogueira, C.E.C., Souza, S.N.M., Micuanski, V.C., Azevedo, R.L., 2015. Exploring possibilities of energy insertion from vinasse biogas in the energy matrix of Paraná State, Brazil. Renew. Sustain. Energy Rev. 48, 300-305, http://dx.doi.org/10.1016/j.rser.2015.04.023.

Oliveira, B.G., Carvalho, J.L.N., Cerri, C.E.P., Cerri, C.C., Feigl, B.J., 2013. Soil greenhose gas fluxes from vinasse application in
Brazilian sugarcane areas. Geoderma 200 (-201), 77-84, http://dx.doi.org/10.1016/j.geoderma.2013.02.005.

Podmirseg, S.M., Seewald, M.S.A., Knapp, B.A., Bouzid, O., Biderre-Petit, C., Peyret, P., Insam, H., 2013. Woos ash amendment to biogas reactors as an alternative to landfilling? A preliminary study on changes in process chemistry and biology. Waste Manage. Res. 31 (8), 829-842, http://dx.doi.org/10.1177/0734242X13497077.

Prada, S.M., Guekezian, M., Suárez-Iha, M.E.V., 1998. Analytical methodology for the determination of sulfate in vinasse. Quím. Nova 21 (3), 249-252, http://dx.doi.org/10.1590/S0100-40421998000300002.

Química e Derivados, 2015. Market- Spot Price without Taxes Collected in São Paulo Between 27 and 30 November 2015 (Year L, n. 563), http://www.quimica.com.br/pquimica/revistas/qd563/index.html. (Accessed 10 04.16). (in Portuguese).

Rolim, M.M., Lyra, M.R.C.C., Duarte, A.S., Medeiros, P.R.F., França e Silva, E.F., Pedrosa, E.M.R., 2013. Influence of a vinasse-distributing lake on water quality of the groundwater. Rev. Ambient. Água 8, 155-171, http://dx.doi.org/10.4136/ambi-agua.1014 (in Portuguese).

Ryan, D., Gadd, A., Kavanagh, J., Barton, G.W., 2009. Integrated biorefinery wastewater design. Chem. Eng. Res. Des. 87, 1261-1268, http://dx.doi.org/10.1016/j.cherd.2009.04.016.

Seth, R., Goyal, S.K., Handa, B.K., 1995. Fixed film biomethanation of distillery spentwash using low cost porous media. Resour. Conserv. Recycl. 14, 79-89, http://dx.doi.org/10.1016/S0921-3449(95)80002-6.

Siqueira, L.M., Damiano, E.S.G., Silva, E.L., 2013. Influence of organic loading rate on the anaerobic treatment of sugarcane vinasse and biogas production in fluidized bed reactor. J. Environ. Sci. Heal. A. 48 (13), 1707-1716, http://dx.doi.org/10.1080/10934529.2013.815535.

Souza, M.E., Fuzaro, G., Polegato, A.R., 1992. Thermophilic anaerobic digestion of vinasse in pilot plant UASB reactor. Water Sci. Technol. 25 (7), 213-222.

Tejada, M., Gonzalez, J.L., 2006. Effects of two beet vinasse forms on soil physical properties and soil loss. Catena 68 (1), 41-50, http://dx.doi.org/10.1016/j.catena.2006.04.025.

van Haandel, A.C., 2005. Integrated energy production and reduction of the environmental impact at alcohol distillery plants. Water Sci. Technol. 52 (1-2), 49-57.

Walsh Jr., J.L., Ross, C.C., Smith, M.S., Harper, S.R., Wilkins, W.A., 1988. Handbook on biogas utilization. U.S. Department of Energy; Environment, Health, and Safety Division-Georgia Tech Research Institute, Atlanta, Georgia, USA.

WHO, 2006. Guidelines for the Safe Use of Wastewater, Excreta and Greywater. WHO, Geneva.

Yu, B., Shan, A., Zhang, D., Lou, Z., Yuan, H., Huang, X., Zhu, N., $\mathrm{Hu}, \mathrm{X} ., 2$ 2015. Dosing time of ferric chloride to disinhibit the excessive volatile fatty acids in sludge thermophilic anaerobic digestion system. Bioresour. Technol. 189, 154-161, http://dx.doi.org/10.1016/j.biortech.2015.03.144. 